\title{
LEGAL STATUS AND PERSPECTIVES OF DEVELOPMENT FOR LAND ASSOCIATIONS IN SLOVAKIA ${ }^{1}$
}

\author{
L’udovít Máčaj \\ Comenius University in Bratislava, Faculty of Law
}

\begin{abstract}
The paper analyses land associations in Slovakia as specific subjects, which are subject to a distinct way of real estate disposal. They are currently regulated by Act No. 97/2013 Coll. on Land Associations as amended ("the Land Associations Act" or "the Act"). For understanding the institutes of this Act, it is necessary to point to the historical circumstances under which these entities emerged. In the first part of this paper, the paper points to this development and then analyses the current legal situation. In the next part, it describes current issues of land associations, focusing on practical circumstances. In the main part, the paper focuses on problems with their functions, their profitability and future development. Finally, in de lege ferenda part, the paper tries to find possible solutions to these problems and the future of land associations.
\end{abstract}

Key words: the land associations, protection of land, perspectives of development, transfer of ownership, e-agriculture

\section{INTRODUCTION}

Land associations are indisputably very specific land managers, as well as landlords of agricultural land, forest managers and they also perform many other tasks. Common properties and commonly cultivated properties as their underlying assets are the specific subject matter of the property right of their members and the way they are handled is very limited.

To be able to explain it sufficiently, we need to get closer to the historical development that has led to the formation of such a special kind of co-ownership and the way of dealing with this real estate. The land association is, by its very nature, the relationship of its members (individuals) to concrete land. Actual land associations in Slovakia are based on historic model of co-ownership, which was created because of the abolishment of feudalism in Hungary in our area. Formation of collective co-ownership on the principles of Roman law began. ${ }^{2}$ Ownership management has developed in such a way that the management of co-ownership does not belong to the co-owner, but to the legal person created by a specific document - the statutes. ${ }^{3}$ Later on, these legal entities were regulated by several legal rules. In general, land associations had been governed by these laws: the Article XIX/1898 on common management of forests and land, which are the undivided property

1 The paper was elaborated within Grant UK No. UK/435/2018 - "Príprava opatrení na zefektívnenie činností pozemkových spoločenstiev", awarded by Comenius University in Bratislava, as part of the grants for $\mathrm{PhD}$. students and young scientists from the University.

2 VRABKO, M. - MÁČAJ, L.: Prevod vlastníckeho práva v pozemkových spoločenstvách. In: Agrarian law of the European Union 2017 [electronic media]: (land relations in agriculture, entrepreneurship in agriculture, EU common agricultural policy). Nitra: Slovenská polnohospodárska univerzita v Nitre, 2018, p. 107.

3 Ibid. 
of private landowners and former urbarium members. It was about conditions of use of forest land. Furthermore, the Article X/1913 on undivided pasture lands, which required the establishment of a pasture community on an organized basis. ${ }^{4}$ Finally, the Article XXXIII/1913 on the Sale of Certain State Real Estate or the replacement of these.

Social changes have come rapidly in the period of socialism. Although the owners of the shares did not lose their property, law abolished urbarium (land associations) as legal entities, and in the first case allowed for the transfer of land use rights to former Unified Collective Farms (JRD), in the latter case the regulation led to that forests commonly used by the abolished entities were transferred to the regional administration of forests or JRD. ${ }^{5}$

The restoration of the activities of land associations took place only in the 1990s by Act No. 229/1991 Coll. on the Adjustment of Ownership Relations to Land and Other Agricultural Property as amended (Restitution Act). For the existence of the land communities, there was significant Act No. 330/1991 Coll. on land adjustments, arrangement of land ownership, land authorities and land communities as amended, which restituted legal relations in accordance with the abovementioned Hungarian Urbarial Laws, and finally Act No. 181/1995 Coll. unambiguously declared all plots of land again as common venture ownership. This law meant a transitional period; one of its aims was to modify the existence of land associations uniformly. It partially succeeded in doing so, but some associations continued to operate based on Hungarian regulations, others as associations of citizens, and only a part within the meaning of this law. Some of them also existed as associations with legal personality, some without it. It was precisely because of this disunity that all existing associations had to become subject to a unified legal regime, and this was done only after the adoption of Act No. 97/2013 Coll. on Land Associations as amended. ${ }^{6}$

\section{LAND ASSOCIATION AS A SUBJECT OF LAW}

\subsection{Current legal status of land associations due to the Land Associations Act}

In valuation of importance of land associations, it is necessary to look at how much land they currently manage in Slovakia, and how important they are to Slovak agriculture as well as forestry.

Nowadays, land associations are obligatorily legal persons regulated by the Land Associations Act. A land association is a legal entity according to the law, and this term includes many entities, which were regulated by different legislation in history. Existence of new land association begins upon the day of registration. The Register of Associations is managed by the District Office, the Land and Forestry Department, the local authority in the district in which the common property, respectively commonly cultivated property is located, respectively its largest part. $^{7}$

To understand the land association as a subject of law, it is appropriate to understand it as an entity that consists of three parts, namely the personal, material and organisational substrate. The

4 BUJŇÁK, J.: Spoločné nehnutelnosti v horizonte zmien a zákonných obmedzení. In: Pozemkové spoločenstvá. História a súčasnost'. Bratislava: Slovenská spoločnost' geodetov a kartografov, 2014, p. 24.

5 VRABKO, M. - MÁČAJ, L.: Prevod vlastníckeho práva v pozemkových spoločenstvách. In: Agrarian law of the European Union 2017 [electronic media]: (land relations in agriculture, entrepreneurship in agriculture, EU common agricultural policy). Nitra: Slovenská pol’nohospodárska univerzita v Nitre, 2018, p. 108.

6 Ibid.

$7 \$ 22$ par. 2 of Act No. $97 / 2013$ Coll. 
association's personal substrate consists of owners of common property as well as owners of commonly cultivated properties. The association is based on the association agreement concluded by the owners of these properties. The members of the association are all owners of shares of common property or owners of commonly cultivated property. Membership is tied to the co-ownership of this property. This is a special kind of property co-ownership, whereby a potential acquirer of a share is obliged, within two months from the date of its acquisition, to accede to the association agreement. The extent of the rights and obligations of the members depends on the amount of their co-ownership; if that is not possible, it is based on the members' agreement. ${ }^{8}$

An indispensable condition of existence of these associations are common properties or commonly cultivated properties, i.e. material (land) substrate, which are under management of concrete land association. The owner of these properties is not an association as such, but mostly a very large number of co-owners. Common property consists of several pieces of land, which together form one immovable, indivisible and massive thing. It is a remnant of the feudal system and special type of co-ownership, which is difficult to leave. On the other hand, commonly cultivated property is owned by concrete owner (or couple of co-owners) and it comes under managing of the association only after free decision of its owner and his/her signature of the association agreement.

The association's organisational substrate is made up of its bodies. These are: the assembly, the committee, the supervisory board and other association bodies established by the association agreement. ${ }^{9}$ The highest authority of the association is the Assembly, which is made up of all members of the association. The assembly has the widest powers, notably the approval of the association agreement, the statutes and their changes, the election and recall of the members of the committee and the supervisory board, and many others concerning actions of association..$^{10}$ The committee is a typical executive body and statutory body, and its role is, in particular, to direct association action and to rule in all cases where the law does not confer on other bodies. It should have at least five members and shall be governed by its President. Another body is the supervisory board, which controls the activities of the association. It has at least three members, and a minority of them does not have to be a member of the association.

\subsection{Transfer of land title in land associations}

When we talk about transfer of land, which is managed by land associations, we must divide it into two types of land: common properties and commonly managed properties.

By law, in the case of common property, it is real estate consisting of several separate lots. ${ }^{11} \mathrm{It}$ is, therefore, one thing that is made up because of evidence from several lots, each of which is made up of same shares. Common property thus creates a special type of co-ownership, which, in relation to the modification of joint estate in the Civil Code, has the status of lex specialis. ${ }^{12}$ However, the

8 VRABKO, M. - MÁČAJ, L.: Prevod vlastníckeho práva v pozemkových spoločenstvách. In: Agrarian law of the European Union 2017 [electronic media]: (land relations in agriculture, entrepreneurship in agriculture, EU common agricultural policy). Nitra: Slovenská pol’nohospodárska univerzita v Nitre, 2018, p. 109.

$9 \$ 13$ par. 1 of Act No. 97/2013 Coll.

$10 \$ 14$ par. 7 of Act No. 97/2013 Coll.

$11 \$ 8$ par. 1 of Act No. 97/2013 Coll.

12 MOLOVÁ, K.: Pozemkové spoločenstvá (4) - Predkupné právo v pozemkových spoločenstvách. In: Ulpianus.sk. Available at: <http://www.ulpianus.sk/blog/pozemkove-spolocenstva-4-predkupne-pravo-v-pozemkovych-spolocenstvach-/ $>$ (accessed on $5^{\text {th }}$ November 2018). 
Land Associations Act also provides that a common property is, in principle, indivisible, except the cases stated in the law. ${ }^{13}$ As the Regional Court of Banská Bystrica stated in its judgment dated 13 December 2012, file no. 24Sp/31/2012, "The court is of the opinion that the transfer may include co-ownership shares (shares of both vendors), but only assuming that the entire group of land constituting the common property would be transferred. Individual owners of shares cannot deal with their shares solely in respect of any allocated land but must always treat all the land which forms the common property up to the amount of their co-ownership." Furthermore, if the owner of the share of the common property wants to sell his co-ownership share to another co-owner of the property, the other co-owners do not have a pre-emption right. Consequently, this situation does not logically apply to cases where ownership is transferred in relation to third parties (who are not co-owners of the property), in which case that pre-emptive right arises for other co-owners.

On the other hand, although from a quantitative point of view on a much smaller scale, land associations also manage commonly cultivated properties, for which there is a completely different, more flexible and more practical legal regime. While in the case of common property its legal regime is based on a historical arrangement of co-ownership relations to concrete plots, in this case it is a manifestation of the free will of the owner of the land to be managed by the association and its owner is to become a member. The commonly cultivated property is therefore not an institution expressing any kind of ownership but is a separate land use institution linked exclusively to the land community institute. These properties do not represent any special type of co-ownership and are subject to full owner's right of transfer.

\section{ACTUAL PROBLEMS CONCERNING LAND ASSOCIATIONS AND POSSIBLE SOLUTIONS}

As mentioned above, most of land managed by land associations is formed by common properties, which have special legal status and creates special type of co-ownership. Because of simple fact that most of co-owners acquired land ownership by succession, they have not been interested in activity of the association and exercise of their owner's rights for many years. As a result, too often there is a situation where such members are a large part, sometimes the overwhelming majority in the association. In this case, the activities of the association bodies are threatened, leading to their non-functioning, and the consequent suppression of the functioning of the association as well as of the pursuit of its business activities. This in turn leads to its worse economic outcomes or its economic collapse.

There are also other problems, which some land associations must deal with. They are linked to rights of the members (i.e. co-owners of common properties), who want to leave the association and separate their own lot from common property. This process is very difficult, not only because of legal regulation of termination of this special model of co-ownership, but also because of interest of the association.

Another task concerning land associations is use of modern information and communication technologies. The problem of the communities is that their activity is in many cases only aimed at redistributing profits from renting agricultural and forest land, approving the transfer of ownership of land and other matters. But to a much lesser extent they are dealing with the development of the

$13 \$ 8$ par. 2 of Act No. $97 / 2013$ Coll. 
association, its possible business and management activities, which, in most cases cede to third parties in the form of a lease agreement. They are less concerned with how to make use of innovation to help them with these activities of the association.

There are many other tasks concerning existence and functions of land associations. In this section, we shall look at some areas, where the functioning of land associations could be improved.

\subsection{Successful and unsuccessful associations}

Nowadays, we can see in Slovakia some land associations as examples of prosperous business model, when they implement their own business policy focused on agricultural and forest management. It is their natural area of business because associations manage mostly these types of land.

The Land Associations Act in relation with the Act No. 326/2005 Coll. on forests as amended (Forests Act) predicts situation when land association (as a legal person) acts like forest manager. This role must be performed by natural person, who is a member or employee in an employment relationship agreed up on permanent time. This person has to be professionally competent to carry out the activities mentioned in Forests Act. ${ }^{14} \mathrm{~A}$ condition for the performance of these activities is the entry in the register of professional forest managers, kept by the competent authority of the state administration of forestry. ${ }^{15}$ For associations itself, it is a favourable way how to manage forests on its behalf.

On the other hand, management of agricultural land is much more difficult to achieve in areas which are common properties owned by members of an association. An association itself is in most cases economically not able to ensure agricultural production. Because of that, the most effective way how to manage agricultural land is to rent it to third parties. In this case, even though it is a property of association members, an association acts only as a manager of these lands, but only members are owners of these lands.

It is worth reflecting on how this business of associations could be supported. One of the most accessible routes will be the simplification of decision-making procedure of association bodies and its greater operability. In many cases, tax relief would also be helpful in activities closely related to the management of the assets of the members of the associations, i.e. the management of common properties and commonly cultivated properties.

\subsection{Transfer of land in land associations}

One of the main problems concerning actions in land associations is the possibility of transfer of land managed by land associations. In fact, this land, i.e. common properties and commonly cultivated properties are owned by members of concrete association, not by association itself (excluding shares owned by association). That is why association cannot transfer ownership to these properties, and it causes difficulty in these transfers.

Another problem arises from the fact that all land, consisting of lots forming a common property, is one independent thing. For this reason, individual lots (as parts of the earth's surface) are not able of being sold without any further process to a third subject since they form one coherent and economically well-utilized whole. In such cases, it is necessary to maintain the procedure ac-

$14 \$ 47$ of Act No. 326/2005 Coll.

$15 \$ 47$ par. 1 and 2 of Act No. 326/2005 Coll. 
cording to the law, according to which it is necessary first to separate part of the common property, then to settle the ownership relations. For now, the Land Associations Act does not include exhaustive reasons for separation of part of common property. In moment, when this part is separated after approval of members of the association, it becomes commonly cultivated property. ${ }^{16}$ However, the property transfer agreement must be concluded by the owners of shares of common property, each separately. Therefore, those shareholders who disagree with the transfer of ownership to this separate part, with its sale, exchange or donation and do not enter into such a contract, remain the co-owners of this separate part of land as a newly created commonly cultivated property, because when the vote was taken, they usually do not sign a contract for the transfer of ownership. Income from the sale of a separate part of the common property is the income of the owners of the common property who have entered into a transfer of association agreement; this also applies to the Slovak Land Fund ("SLF") as a manager of some shares.

A special feature of the common property, unlike other types of real estate, is, inter alia, the lawful exclusion of the cancellation and settlement of co-ownership of common property. The consequence is the permanent binding of co-owners of common property without the possibility of partial settlement and cancellation of co-ownership of only one or several co-owners and the creation of several common properties. The intention is to avoid further tumbling of the common property, which is already a major problem. ${ }^{17}$ According to older legislation, even transfer of ownership to shares in the common property to the association itself was prohibited. Nowadays, the Land Associations Act provides that the transfer of ownership of a share of common property to the association is prohibited if the share in common property or commonly cultivated property exceeds 49 percent. ${ }^{18}$ This change can contribute to greater flexibility, greater autonomy and economic success of the community, as this leaves it with greater decision-making autonomy by its bodies. There is no doubt that the transfer of ownership requires that the will of the co-owners be preserved, so we can fundamentally consider this adjustment to be correct although in practice it causes problems.

\subsection{Possible changes of decision-making procedures of association bodies}

The basis for the organization of relations among bodies of association is the precise definition of their powers in the first place in the Land Associations Act, as well as in the association agreement or, where appropriate, in statutes of the association. There must exist effective separation of powers among them.

The most important powers are those of the assembly, which consists of all members of the association. The Act provides a relatively detailed calculation of the tasks that fall within the competence of the assembly. ${ }^{19}$ Even though it is a taxable calculation, the Act allows the Assembly to decide on other matters of the association if the decision is not entrusted to other association bodies. First, this includes the approval and possible amendment of the association agreement as well as the association statutes. Each member of the association has the ratio of votes at the Assembly equal to the proportion of the participation of a member of the association in the exercise of rights and obligations determined

$16 \$ 8$ par. 2 of Act No. 97/2013 Coll.

17 ILLÁŠ, M.: Spôsoby nakladania so spoločnou nehnutelnostou. In: Pozemkové spoločenstvá. História a súčasnost'. Bratislava: Slovenská spoločnost' geodetov a kartografov, 2014, p. 33.

$18 \$ 9$ par. 11 of Act No. 97/2013 Coll.

$19 \$ 14$ par. 7 of Act No. 97/2013 Coll. 
by the size of their shares in the common property. If, due to the ownership of multiple common properties registered on multiple ownership certificate this proportion cannot be determined, it may be determined by agreement of the members of the community or by a decision of the assembly. The Act further specifies the cases in which it decides by an absolute majority of the votes of all the members of the association and in which it decides by an absolute majority of the votes of members of the association whose shares in common immovable property are not managed by the SLF or whose shares in the commonly cultivated property are not managed by the administrator. ${ }^{20}$ While there is no doubt that in many matters concerning the legal status of the association itself (such as the adoption and amendment of the association agreement and the statutes) it is necessary to maintain this arrangement, it is worth considering whether in cases such as decision-making on profit sharing, and the conditions of entry of the association into a business organisation or cooperative society and the decision on other economic matters these could be left to the majority of the members of the association participating in the assembly. This would make the association more operational and based on decisions by active members, the association could start to engage in new business activities.

On the other hand, the committee is the most important body for the performance of several activities of the association. The Act defines it as an executive and statutory body of the association. It governs association actions and decides on all matters for which it is empowered by the Act, the association agreement, the statutes or other kind of decision of the assembly. The committee shall have at least five members. The committee shall be organized and managed by the President of the association. The President of the association is elected by the committee from among its members unless otherwise provided in the association agreement or the statutes. ${ }^{21}$ The committee, personally represented by the President of the association, is therefore the body with the task of ensuring dayto-day activity and action of the association. If the legislature were to make associations' activities more effective, it would be worth considering whether it would not be possible to strengthen its powers by delegating certain tasks from the assembly to the committee, e.g. such as the business use of property managed by the association.

\section{CONCLUSION}

The aim of this paper was to focus more closely on the legal status of land associations in the Slovak legal order as well as on the perspectives of their further development. They, as legal units based in the legal history of our nation, are currently facing a challenge to cope with the challenges of modern times. These are facts such as the failure of the members of the association to exercise their rights and obligations arising from membership of the associations and the co-ownership of particular common property. Other problems exist due to the fact of failure to hear and determine several coownership shares in common property in the succession proceedings or a large number of shares of common properties whose ownership is unknown or unidentified and thus, according to the law, finds itself in the SLF management.

Addressing this situation is to adapt the work of the association bodies to the new situation to make their decision-making more appropriate and operational. Issues relating to routine manage-

$20 \$ 15$ par. 2 of Act No. 97/2013 Coll.

$21 \$ 16$ par. 3 of Act No. 97/2013 Coll. 
ment and possible business would be appropriate to be delegated to a committee that acts as a permanent executive body of the association. On the other hand, even in cases where it seriously affects the legal status of a particular association, it would also be appropriate to use a different decisionmaking quorum, such as the decision by a simple majority of only the members of the association present at concrete assembly.

Despite everything, there is no doubt that due to the size of the territory in administration of land communities, these legal units continue to have meaning and need to exist in our legal order and some modernization measures could simplify their activities.

\section{Bibliography:}

BUJŇÁK, J.: Spoločné nehnutelnosti v horizonte zmien a zákonných obmedzení. In: Pozemkové spoločenstvá. História a súčasnost'. Bratislava: Slovenská spoločnost geodetov a kartografov, 2014, p. 20-25. ISBN 978-80-89626-02-1.

ILLÁŠ, M.: Spôsoby nakladania so spoločnou nehnutelnostou. In: Pozemkové spoločenstvá. História a súčasnost'. Bratislava: Slovenská spoločnost’ geodetov a kartografov, 2014, pp. 33-41. ISBN 978-80-89626-02-1.

MOLOVÁ, K.: Pozemkové spoločenstvá (4) - Predkupné právo v pozemkových spoločenstvách. In: Ulpianus.sk. Available at: http://www.ulpianus.sk/blog/pozemkove-spolocenstva-4-predkupne-pravo-v-pozemkovych-spolocenstvach-/ (accessed on $5^{\text {th }}$ November 2018).

VRABKO, M. - MÁČAJ, L.: Prevod vlastníckeho práva v pozemkových spoločenstvách. In: Agrarian law of the European Union 2017 [electronic media]: (land relations in agriculture, entrepreneurship in agriculture, EU common agricultural policy). Nitra: Slovenská polnohospodárska univerzita v Nitre, 2018, pp. 105-115. ISBN 978-80-5521796-3.

\section{Legislation:}

Act No. 97/2013 Coll. on land associations as amended

Act No. 326/2005 Coll. on forests as amended

\section{Contact information:}

Mgr. Ludovít Máčaj

ludovit.macaj@flaw.uniba.sk

Comenius University in Bratislava, Faculty of Law

Šafárikovo Sq. No. 6

81000

Bratislava 1

Slovakia 